Jurnal Keuangan dan Perbankan, Vol.19, No.3 September 2015, hlm. 357-367

Terakreditasi SK. No. 040/P/2014

http://jurkubank.wordpress.com

\title{
FOREIGN INSTITUTIONAL OWNERSHIP ANDSTOCK RETURN VOLATILITY IN INDONESIA
}

\author{
Irwan Adi Ekaputra \\ DepartemenM anajemen, FakultasEkonomidanBisnis, Universitas Indonesia \\ Kampus UI, Depok 16424, Indonesia
}

\begin{abstract}
This paper examines theimpact of foreign institutional ownership on contemporaneous stock return volatility in Indonesia. In this study, return volatility is measured as standard deviation of daily stockreturns. The dynamic panel data results based on System GM M (S-GM M ) estimation, confirm that foreign institutional ownership tend to linearly and convexly increase monthly stock return volatility. Thelinear impact sems to be weaker for stocks with higher market capitalization, but stronger for stocks with higher turnover.F urthertest reveals that foreign financial institutional ownershiplinearly contributes to return volatility upsurge, while foreign non-financial corporation ownership convexly contributeto return volatility increase.T headditional test also uncovers that domestic financial and non-financial institutionalownerships do not impact return volatility.
\end{abstract}

Keyw ords:capital market liberal ization;general methods of moments; institutional ownership;volatility; Indonesia

\section{FOREIGN INSTITUTIONAL OWNERSHIP AND STOCK RETURN VOLATILITY IN INDONESIA}

The debate on the benefits and costs of opening up capital markets in emerging economies is far from over. Since domestic emerging market volatility tends to be larger than developed market, some studies reveal that one of the benefits ofliberalizing local capital market islower cost of capital (Bekaert \& Harvey, 1997; Henry,
2000). In fact, Bekaert \& Harvey (2000)reveals that the cost of capital in emerging economies decreases between 5 and 75 basis points after capital market liberalization. Other evidence suggests other benefits of emerging market liberalization. It facilitates international information transmission (Bae, Ozoguz, Tan, \& Wirjanto, 2012), improves corporate governance (Huang \& Zhu, 2014), increases stock market trading and capitalization (dela Torre, Gozzi, \& Schmukler, 2007), and spurs economic

KorespondensidenganPenulis:

Irwan Adi Ekaputra: Telp. +62 217272425

Email: irwan.adi@ui.ac.id; irwanekaputra@hotmail.com 


\section{Jurnal Keuangan dan Perbankan | KEUANGAN}

Vol. 19, N o.3, September 2015: 357-367

growth (Bekaert, Harvey, \& Lundblad, 2005; Bekaert, Harvey, \& Lundblad, 2011).

However, other studiesdiscover that capital market liberalization does not bring significant benefits. Ithas not created faster growth, but has created greater externalities and risks (Stiglitz, 2002).Furthermore, the welfare gain from opening up the capital market is negligible compared to welfare gain from improving domestic productivity (Gourinchas \& Jeanne, 2006).

After few incidences of financial crises, one prominent growing concern discussed in the literature is whether foreign capital flowand participation increase emerging stock market volatility. Volatility is an important aspect in financial economics, due to its strong relations with expected return, international risk sharing,andcost of capital. Bekaert \& Harvey (1997) suggest that capital market liberalization may increase or decrease emerging market volatility, depending on the prior state of the market. If domestic factors are more volatile than world factors, liberalization may reduce stock volatility. On the contrary, if international market risk is higher than domestic market risk, the liberalization may increase volatility. Indeed, empirical studies generate inconclusive results whether foreign ownership and trade reduce or increase local emerging market volatility.

Some studies support the notion that opening up emerging capital market to foreign investor reduces stock return volatility. Theresult based on 25 emerging markets, suggest that financial liberalization leads to reduction of total stock return volatility(Umutlu, A kdeniz, \& Altay-Salih, 2010). A nother study of 31 emerging markets, also finds that large foreign ownership reduces stock return volatility(Li, N guyen, Pham, \& Wei, 2011). Similar result is exhibited in a study based on the removal of ownership restrictions on China'sA-share market. It confirms that foreign institutions tend to stabilizeChinesestock market (Schuppli \& Bohl, 2010).
In contrast, other studies reveal that foreign investor participation in emerging market increases volatility. Based on 45 emerging markets data, Bae, Chan, \& Ng (2004) find that highly investible emerging market stocks tend to exhibit higher stock return volatility. M eanwhile, foreign equity trading exhibits the highest explanatory power for market volatility in Indonesia and Thailand (Wang, 2007). Even after controlling for other factors, foreign institutional ownership in China increases firm-level return volatility (Chen, Du, Li, \& Ouyang, 2013).

Due to 1997 A sian financial crisis, Indonesia has liberalized completely its capital market since January 28, 1998. Since then, foreign investors are allowed to buy all outstanding shares of Indonesian listed companies. In Indonesian Rupiah (IDR) terms, domestic investor ownership increases from around IDR 379 trillion in 2009 to slightly more than IDR 1,040 trillion in 2012. During the same period, foreign investor ownership increases from about IDR 772 trillion to around IDR 1,484 trillion. In terms of proportion, domestic ownership increases from 32.90 percent in 2009 to 58.79 percent in 2012, while foreign ownership decreases from 67.10 percent to 58.79 percent.

To increase global competitiveness and Iiquidity of Indonesian capital market, on December 1, 2007, Jakarta Stock Exchange and Surabaya Stock Exchange merged themselves to become the Indonesian Stock Exchange (IDX).Moreover, to protect unwarranted trade and manipulation, starting on February 1, 2012, the Indonesian Central SecuritiesDepository (ICSD) implements Single Investor Identification (SID) system. The system requires stock brokers to identify the ultimate owner of each trade submitted to IDX. SID implementation makes more detailed stock ownership classification data readily available.

This study is motivated at least by three reasons. Firstly, SID implementation creates availability of new more detailed stock ownership data. 


\section{Foreign Institutional Ownership Andstock Return Volatility In Indonesia}

Irwan Adi Ekaputra

Secondly, although some studies have presented evidence from Indonesian market, to the best of author's knowledge there has not been any study on foreign institutional ownership impact on firm level stock volatility. The closest paper is (Wang, 2013) which documents stabilizing effect of foreign ownership on future stock volatility. A part from the methodology, there are at least two main differences: (1) his study does not use SID foreign institutional ownership data which is crucial as inferred in (Li, N guyen, Pham, \& Wei, 2011), (2) his paper uses the Asian financial crisis as its period of interest, while this study distances itself from major financial crises period to minimizetheir impact on stock return volatility. Thirdly, a country-specific study may generate different conclusions from a cross-country study as shown in China by (Chen, Du, Li, \& Ouyang, 2013)compared to (Li, N guyen, Pham, \& Wei, 2011)which also includes China as its sample.

Thispaper confirms that foreign institutional ownership tend to linearly and convexly increase contemporaneous monthly stock return volatility. The results are drawn from dynamic panel data models. The linear impact of foreign institutional ownership seems to be weaker for stocks with higher market capitalization, but stronger for stocks with higher turnover. Further testsindicate that foreign financial institutions linearlyincreaseconcomitant monthly stock return volatility. Meanwhile, foreign non-financial corporation convexly increase contemporaneous return volatility. The additional test also concludes that domestic financial and non-financial institutional ownershipsdo not destabilizethe Indonesian market.

The rest of the paper is organized as follows. Section two discusses three main hypotheses of this research. Section three presents data and methodology. The methodology will explain the dynamic panel data model. Section four provides and discusses the main results. Section five delivers and deliberates the additional test results. Section six offers some concluding remarks.

\section{Main Hypotheses}

Previous studies document that Indonesian stock market is thin and illiquid. Foreign institutional ownership in Indonesia tends to reduce liquidity, defying the view that foreign institutions will improve liquidity(Rhee \& Wang, 2009). Furthermore, (Bonser-N eal, Linnan, \& N eal, 1999) discoverat least three facts about Indonesian market: (1) transaction costs are higher to trade small firms than to trade large firms; (2) price impact of trades is higher for small firms than large firms; and (3) trades initiated by foreign investors significantly cause a larger impact on prices, than trades initiated by domestic investors. Hence,the presence of foreign institutions in Indonesian market may increase volatility, due tolower stock liquidityand higher price impact that they create.

Additionally, the impact of foreign institutional ownership on volatility should belower for large stocks. When foreign institutions decide to invest in large stocks, most likely they will trade with other foreign or domestic institutions. It is because institutional investors display "large firm bias" where they like to invest in stocks with high market liquidity (Dahlquist \& Robertsson, 2001). Priceimpact is higher when institutions trade with individuals, but no such pattern is indicated when institutions tradewith each other (Stoffman, 2014). There should be no investibility issue (Bae, Chan, $\& N$ g, 2004)between small and large stocks, since all stocks are open to foreign investors.

Similar studies in Indonesia (Wang, 2013) and China (Chen, Du, Li, \& Ouyang, 2013) document non-linear impact of foreign ownership to stock volatility. Due to market illiquidity in Indonesia, I deduce that foreign institutional ownership will exhibit u-shape (convex) impact on stock return volatility. Hence, three main hypotheses of this research are as follows: 


\section{Jurnal Keuangan dan Perbankan | KEUANGAN}

Vol. 19, N 0.3, September 2015: 357-367

Hypothesis one: Foreign institutional ownership increases stock volatility in Indonesian market.

Hypothesis two: The positive impact of foreign institutional ownership on volatility is less pronounced in larger size stocks.

Hypothesis three: Foreign institutional ownership exhibits non-linear (convex) impact on stock volatility.

\section{Data and Methodology} Data

This study collects end of month ownership data of each stock from the Indonesian Central Securities Depository (ICSD). Other data related to price, transaction value, and number of outstanding shares is collected from the Indonesian Stock Exchange (IDX). In early 2012, there were 441 stocks listed in IDX. After removing stocks experiencing suspensions and incomplete records, this research only includes 422 stocks as the sample. The sample period starts from February, 2012 until September, 2013.

The sample should consist of 422 stocks (cross-sections) and 20 months (periods), or 8440 balanced-panel observations. However, two unreliableobservations are removed due to suspected erroneous data recording leading to domestic institutional ownership that is more than 100 percent. Two stocks displaying domestic institutional ownership more than 100 percent are MEGA in June 2013 and AGRO in A ugust 2013. Hence, both observations are removed and the sample is unbalanced with 8438 observations.

Following SID classifications, I define institutional ownership as the sum of ownership of six categories: (1) insurance, (2) pension fund, (3) investment bank, (4) mutual fund, (5) stock brokerage company, and (6) corporation.

\section{Variables}

In this study, the dependent variable of interest is firm-level stock return volatility (V O LA T), while the main independent variable of interest is foreign institutional ownership (FORINST). VOLAT is monthly standard deviation of daily stock returns, while FORINST is foreign institutional ownership (in number of shares) divided by total shares outstanding at theend of month.To investigate non-linear impact of FORINST on VOLAT, the modelalso uses the squared ofFORIN ST (FO RIN ST ${ }^{\wedge}$ 2) as theindependent variable.

In addition, this study also employs three main control variables: (1) DOM INST is domestic institutional ownership of each stock (in number of shares) divided by its total shares outstanding at the end of month; (2) SIZE is natural logarithm of each stock market capitalization at the end of month; (3) TUR N OVER is monthly stock transaction value divided by its market capitalization. Finally,the model also contains interactions of SIZE and TURNOVER with FORIN ST and DOM INST.

\section{Dynamic Panel Data}

Following (Chen, Du, Li, \& Ouyang, 2013), this study includes lag of V OLAT as an additional regressor. The inclusion of lag V O LAT producesa dynamic panel data structure. To address endogeneity issue, different from (Chen, Du, Li, \& Ouyang, 2013), this study does not conduct regressions in first-difference, but opts to apply dynamic panel data estimation method known as the System GMM (S-GMM) (Arellano \& Bover, 1995; Blundell \& Bond, 1998). The base empirical models are presented in Eq. (1) and (2):

$$
\begin{aligned}
\operatorname{VOLAT}_{i, t}= & \beta_{0}+\beta_{1} \text { VOLAT }_{t-1}+\beta_{2} \text { FORINST }_{i, t}+ \\
& \sum \beta_{i} \text { Control }_{i, t}+\varepsilon_{i, t}
\end{aligned}
$$




\section{Foreign Institutional Ownership Andstock Return Volatility In Indonesia}

Irwan Adi Ekaputra

$$
\begin{aligned}
\operatorname{VOLAT}_{i, t}= & \delta_{0}+\delta_{1} \text { VOLAT }_{t-1}+\delta_{1} \text { FORINST }_{i, t}+ \\
& \delta_{2} \text { FORINST }_{i, t}+\sum \delta_{i} \text { Control }_{i, t}+\varepsilon_{i, t}
\end{aligned}
$$

WhereV OLA $T_{i, t}$ is daily stock return volatility of stock-i during month-t.VOLAT $T_{i,-1-1}$ is previous month (lag) stock return volatility. FO RIN ST ${ }_{i, t}$ is foreign institutional ownership of stock-i (in number of shares) divided by its total shares outstanding at the end of month-t.FORINST^ $2_{i, t}$ is FORINST ${ }_{i, t}$ squared which is used to investigate non-linear impact of FORINST on VO LAT. Mean-

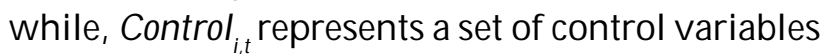
as described in the previous section.

S-GMM dynamic panel estimators are suitable for the data in this study since it is a relatively short period (20 months)compared to itscross section data (422 stocks). They are also suitable for independent variables that are not strictly exogenous. In this study TU RN OVER may be endogenous to VOLAT since higher VOLAT suggests more trading activity which will be re flected in TURN OVER (Esqueda, A ssefa, \& Mollick, 2012). Another advantage of using S-GM M is to handle unobservabletime-invariant firm characteristics that may affect both VOLAT and FORIN ST (Chen, Du, Li, \& Ouyang, 2013). Moreover, the use of S-GMM will avoid dynamic panel data bias, known as Nickel bias, that arises from using least squares estimators (N ickell, 1981).

S-GM M is originated from (A rellano \& Bond, 1991) estimator which commences by transforming all regressors, and then applies the Generalized Method of Moments (GMM). The transformation is usually done by takingthe first difference of the variables, hence removing the fixed effects andproducing additional equation that can be estimated using suitable lags of endogenous explanatory variables as theinstrumental variables. To produce more robust estimators, S-GMM makes additional assumption that first differences of instrument variables are not correlated with the fixed effects. Hence, lags of first differences are employed in addition to the lags of the endogenous explanatory variables.

S-GMM estimators are considered to beconsistent if the residuals do no exhibit second order autocorrelation. To check this condition this study employs(Arellano \& Bond, 1991)AR(2) tests. Additionally, instrumental variables employed must be valid. To check the validity this study employs both Sargan and Hansen tests. The joint null-hypotheses are: (1) instrument variables are independently distributed of the error process, and (2) instrument variables arecorrectlyomitted from the model.

\section{Results and Discussions \\ Descriptive Statistics}

The descriptive statistics is presented in Table 1. It shows that the average and the median stock return volatility are 0.0259 and 0.0214 respectively. The stock experiencing the highest return volatility of 2.1654is BRMS (PT. Bumi Resources Minerals, Tbk.)which happens in July 2012.Further examination of the data reveals that the stock also experiences high return volatility of 2.1089 in July 2013. A pparently, the stock which is a subsidiary of Bakrie Groupis very volatile during the study period.

During this research period, two stocks: BAEK (PT. Bank Ekonomi Raharja, Tbk.) and LPPF (PT. Matahari Department Store, Tbk.) register the highest foreign institutional ownerships of around 99.99 percent for several months. On the contrary, TIRA (PT. Tira Austenite, Tbk.) records the largest domestic institutional ownerships of around 99.41 percent during July-August 2013. In terms of market capitalization, HMSP (PT. HM . Sampoerna, Tbk.)is the largest stock during MayAugust 2013, while TIFA (PT. Tifa Finance, Tbk.) is the most actively traded stock in February 2013. 


\section{Jurnal Keuangan dan Perbankan | KEUANGAN}

Vol. 19, N 0.3, September 2015: 357-367

From the Pearson correlations presented in Table 2, VOLAT is positively correlated with TURN OVER, FORINST, and DOM INST. HOWever, the correlation between VOLAT and FORIN ST is stronger than V OLAT and DOM INST. This may indicate that foreign institutional ownership tends to increase stock volatility, more than domestic institutional ownership.

Meanwhile, thecorrelations betweenV OLAT and SIZE, and betweenDOM INST and FORINST are both negative. The negative correlation between VOLAT and SIZE may indicate that large stocks are less volatile than small stocks. In the meantime, the negative correlation between DOM IN ST and FORIN ST may indicate that both of them tend to transact in different directions.

\section{Dynamic Panel Results}

The complete estimation results of the dynamic panel data models are presented in Table 3. The results based on Eq. (1) and (2)in the second and third columns of Table 3 , show thatthe coefficients of Lag(VOLAT) are significantly positive. They correspond with the notion that return volatility tend to cluster. One period of high return volatility tends to follow another period of high return volatility.

With respect to the first hypothesis, the results document the positive linear impact of FORINST on VOLAT. These findings support the first hypothesis that predicts foreign institutional ownership positive linear impact on stock return

Table 1. Descriptive statistics.

\begin{tabular}{crrrrrr}
\hline Variable & Observations & \multicolumn{1}{c}{ M ean } & Median & $\begin{array}{r}\text { Standard } \\
\text { Deviation }\end{array}$ & Minimum & Maximum \\
\hline VOLAT & 8438 & 0.0259 & 0.0214 & 0.0447 & 0 & 2.1654 \\
FORINST & 8438 & 0.1903 & 0.0924 & 0.2414 & 0 & 0.9999 \\
DOMINST & 8438 & 0.2426 & 0.1351 & 0.2675 & 0 & 0.9941 \\
SIZE & 8438 & 27.8886 & 27.7437 & 2.0432 & 23.1948 & 33.5688 \\
TURNOVER & 8438 & 0.0296 & 0.0057 & 0.0703 & 0 & 0.9572 \\
\hline
\end{tabular}

VOLAT is monthly standard deviation of daily return. FORINST is the proportion of foreign institutional ownership. DOM INST is the proportion of domestic institutional ownership. FORFIN is the proportion of foreign financial institutional ownership. FORCORP is the proportion of foreign nonfinancial corporation. DOM FIN is the proportion of domestic institutional ownership. DOMCORP is the proportion of domestic non-financial corporation.SIZE is the natural log of market cap. TURNOVER is monthly transaction value relative to its market cap.

Table 2 Pearson correlations between variables

\begin{tabular}{cccccc}
\hline & VOLAT & FORINST & D OM INST & SIZE & TURN OVER \\
\hline VOLAT & 1.0000 & & & & \\
FORINST & 0.0192 & 1.0000 & & & \\
DOMINST & 0.0129 & -0.2016 & 1.0000 & & \\
SIZE & -0.0263 & 0.2293 & -0.0099 & 1.0000 & \\
TURNOVER & 0.0999 & -0.0333 & 0.0691 & -0.0557 & 1.0000 \\
\hline
\end{tabular}

VOLAT is monthly standard deviation of daily return. FORINST is the proportion of foreign institutional ownership. DOM INST is the proportion of domestic institutional ownership. FORFIN is the proportion of foreign financial institutional ownership. FORCORP is the proportion of foreign nonfinancial corporation. DOM FIN is the proportion of domestic institutional ownership. DOMCORP is the proportion of domestic non-financial corporation.SIZE is the natural log of market cap. TURNOVER is monthly transaction value relative to its market cap. 


\section{Foreign Institutional Ownership Andstock Return Volatility In Indonesia}

Irwan Adi Ekaputra

Table 3 Dynamic panel data estimation results, based on two-step System GM M (S-GM M). The dependent variable is monthly standard deviation of daily return (VOLAT). Coefficients of the regressors are reported with Windmeijer corrected standard errors in parentheses.Coefficients of Period dummy (MONTH) variables are included but not reported. FORINST is the proportion of foreign institutional ownership. DOM INST is the proportion of domestic institutional ownership. SIZE is the natural log of market cap. TURNOVER is monthly transaction value relative to its market cap. FORINST^2 is FORINST squared. DOM INST^² is DOM INST squared.

\begin{tabular}{|c|c|c|}
\hline & $\begin{array}{c}\text { (1) } \\
\text { Coefficient } \\
\text { (Standard error) }\end{array}$ & $\begin{array}{c}\text { (2) } \\
\text { Coefficient } \\
\text { (Standard error) }\end{array}$ \\
\hline Intercept & $\begin{array}{c}0.0042 \\
(0.0047)\end{array}$ & $\begin{array}{l}-0.0038 \\
(0.0048)\end{array}$ \\
\hline Lag(VOLAT) & $\begin{array}{c}0.8822^{* * *} \\
(0.0503)\end{array}$ & $\begin{array}{l}0.8696^{\text {kek }} \\
(0.0508)\end{array}$ \\
\hline FORINST & $\begin{array}{l}0.0211^{*} \\
(0.0161)\end{array}$ & $\begin{array}{l}0.0270^{* *} \\
(0.0154)\end{array}$ \\
\hline DOMINST & $\begin{array}{c}0.0088 \\
(0.0106)\end{array}$ & $\begin{array}{c}0.0050 \\
(0.0116)\end{array}$ \\
\hline SIZE & $\begin{array}{l}0.00005 \\
(0.0002)\end{array}$ & $\begin{array}{l}0.00025 \\
(0.0002)\end{array}$ \\
\hline TURNOVER & $\begin{array}{l}0.0586 \text { **k } \\
(0.0090)\end{array}$ & $\begin{array}{l}0.0588^{* 1 *} \\
(0.0091)\end{array}$ \\
\hline FORINST*SIZE & $\begin{array}{l}-0.0007 * \\
(0.0006)\end{array}$ & $\begin{array}{l}-0.0012^{* *} \\
(0.0006)\end{array}$ \\
\hline DOMINST*SIZE & $\begin{array}{l}-0.0003 \\
(0.0004)\end{array}$ & $\begin{array}{l}-0.0004 \\
(0.0004)\end{array}$ \\
\hline FORINST*TURNOVER & $\begin{array}{c}0.0663^{*} \\
(0.0353)\end{array}$ & $\begin{array}{l}0.0683^{*} \\
(0.0367)\end{array}$ \\
\hline DOMINST*TURNOVER & $\begin{array}{l}-0.0309 \\
(0.0204)\end{array}$ & $\begin{array}{l}-0.0296 \\
(0.0205)\end{array}$ \\
\hline FORINST^2 & & $\begin{array}{l}0.0103^{* *} \\
(0.0052)\end{array}$ \\
\hline DOMINST^2 & & $\begin{array}{c}0.0063 \\
(0.0044)\end{array}$ \\
\hline $\begin{array}{l}\text { Sargan test } \\
\text { (p-value) }\end{array}$ & $\begin{array}{l}14.90 \\
(0.729)\end{array}$ & $\begin{array}{l}15.01 \\
0.722\end{array}$ \\
\hline $\begin{array}{l}\text { Hansen test } \\
\text { (p-value) }\end{array}$ & $\begin{array}{c}17.79 \\
(0.536)\end{array}$ & $\begin{array}{c}17.44 \\
(0.560)\end{array}$ \\
\hline $\begin{array}{l}\text { AB test for AR(2) } \\
\text { (p-value) }\end{array}$ & $\begin{array}{c}1.28 \\
(0.199)\end{array}$ & $\begin{array}{c}1.28 \\
(0.200)\end{array}$ \\
\hline No. of Instruments & 47 & 49 \\
\hline No. of Observations & 8014 & 8014 \\
\hline
\end{tabular}

*significant at 10 percent level; **significant at 5 percent level; ***significant at 1 percent level.

$A B$ test for $A R(2)$ : test of residuals second order autocorrelation (Arellano \& Bond, 1991). 


\section{Jurnal Keuangan dan Perbankan | KEUANGAN}

Vol. 19, N 0.3, September 2015: 357-367

volatility. This finding is in line with the Chinese market evidence (Chen, Du, Li, \& Ouyang, 2013).

Although the findings in Indonesia and China are the same, the China evidence is caused by weak corporate governance and inadequate regulation, while the Indonesia evidence is due to market illiquidity. Foreign institutional presence absorbs liquidity in the market, which in turn will increase volatility through higher priceimpact.This conjecture is based on the work of Rhee \& Wang (2009) documenting illiquidity increase due to foreign institutional ownership.

With regards to thesecond hypothesis, Table 3 indicates that the coefficients of FORIN ST *SIZE in models (1) and (2)are both significantly negative at 10 percent and 5 percent level respectively. Theseresults support the second hypothesis, which predicts that the impact of foreign institutional ownership on stock return volatility is lower for larger cap stocks. This finding suggests that large cap stocks are less prone to the destabilizing impact of foreign institutional ownership, while the opposite is true for small cap stocks.

The coefficients ofD OM INST in both models are not significant. D O M IN ST*SIZE coefficients are negative but not significant. The negative coefficients tend to support the conception that domestic institutional investors appear to absorb price impact by providing liquidity to foreign institutional investors. This scenario is likely to happen in large stocks since both domestic and foreign institutional investors prefer to invest in large stocks (Dahlquist \& Robertsson, 2001).

The TU RN O VE R coefficientsare persistently and significantly positive. This confirmation is consistent with the findings of previous studies by (Chen, Du, Li, \& Ouyang, 2013;Wang, 2013; Li, N guyen, Pham, \& Wei, 2011) who also use TU RN OVER as one of their control variables. Highly traded stocks tend to exhibit higher stock return volatility.
The coefficients of FORIN ST*T URN OVER are also positively significant. The impact of foreign institutional ownership on stock return volatility appears to be stronger in stocks with higher turnover. This outcome is most likely caused by the illiquidity of the Indonesian market. As Rhee \& Wang(2009) point out, when foreign institutions hold large proportion of Indonesian shares, the liquidity will worsen. In low liquidity market, the influence of stock transactions on price and return volatility will be stronger.

Pertaining to the last hypothesis, the coefficient of FO RINST ${ }^{\wedge} 2$ in model (2)aresignificantlypositive. The resultsupports the third hypothesis which expects foreign institutional ownershiptonon-linearly (convexly) impacts stock return volatility. M eanwhile the coefficient of D O M IN ST $\wedge 2$ is insignificant, supporting the notion that domestic institutional ownership does not destabilize Indonesian market.

The Sargan and Hansen tests on all models do not reject joint null hypotheses that the instruments are independently distributed of the error, and they are properly omitted from the model. Moreover, the AB (Arellano \& Bond, 1991) AR(2) tests show that the residuals do not exhibit second order autocorrelation, which means the SGMM estimators are considered to be consistent.

\section{Additional Test}

Following Chen, Du, Li, \& Ouyang(2013), I conduct additional test to learn whether foreign financial institutions and non-financial institutions impact volatility differently. As explained previously, I define institutional investors to comprise of: (1) insurance, (2) pension fund, (3) investment bank, (4) mutual fund, (5) stock brokerage company, and (6) corporation. In the additional test, institutions (1) to (5) are categorized as financial institutions, while institution (6) is categorized as non-financial corporation. Hence, (foreign) [domes- 


\section{Foreign Institutional Ownership Andstock Return Volatility In Indonesia}

Irwan Adi Ekaputra

Table 4 Dynamic panel data estimation results, based on two-step System GM M (S-GM M). The dependent variable is monthly standard deviation of daily return (VOLAT). Coefficients of the regressors are reported with Windmeijer corrected standard errors in parentheses. Coefficients of Period dummy (M ONTH) variables are included but not reported. FORFIN is the proportion of foreign financial institutional ownership. FORCORP is the proportion of foreign non-financial corporation. DOM FIN is the proportion of domestic institutional ownership. DOM CORP is the proportion of domestic non-financial corporation. FORFIN^2 is FORFIN squared. FORCORP^2 is FORCORP squared. DOM FIN^2 is DOM FIN squared. DOM CORP^2 is DOM CORP squared.

\begin{tabular}{|c|c|c|}
\hline & $\begin{array}{c}\text { (3) } \\
\text { Coefficient } \\
\text { (Standard error) }\end{array}$ & $\begin{array}{c}\text { (4) } \\
\text { Coefficient } \\
\text { (Standard error) }\end{array}$ \\
\hline Intercept & $\begin{array}{l}-0.0084 \\
(0.0050)\end{array}$ & $\begin{array}{l}-0.0093 \\
(0.0055)\end{array}$ \\
\hline Lag(VOLAT) & $\begin{array}{l}0.8767^{* 1 *} \\
(0.0518)\end{array}$ & $\begin{array}{l}0.8565^{* 1 *} \\
(0.0529)\end{array}$ \\
\hline FORFIN & $\begin{array}{l}0.0619 \text { kk } \\
(0.0280)\end{array}$ & $\begin{array}{l}0.0530^{* k} \\
(0.0258)\end{array}$ \\
\hline FORCORP & $\begin{array}{l}-0.0014 \\
(0.0241)\end{array}$ & $\begin{array}{c}0.0014 \\
(0.0207)\end{array}$ \\
\hline DOMFIN & $\begin{array}{c}0.0081 \\
(0.0232)\end{array}$ & $\begin{array}{l}0.00348 \\
(0.0205)\end{array}$ \\
\hline DOMCORP & $\begin{array}{c}0.0125 \\
(0.0113)\end{array}$ & $\begin{array}{c}0.0067 \\
(0.0136)\end{array}$ \\
\hline SIZE & $\begin{array}{c}0.00022 \\
(0.00018)\end{array}$ & $\begin{array}{c}0.0003 \\
(0.0002)\end{array}$ \\
\hline TURNOVER & $\begin{array}{l}0.0597^{* 1 *} \\
(0.0089)\end{array}$ & $\begin{array}{l}0.0599 * 1 * 1 \\
(0.0090)\end{array}$ \\
\hline FORFIN*SIZE & $\begin{array}{l}-0.0022^{* *} \\
(0.0010)\end{array}$ & $\begin{array}{l}-0.0018^{\text {*3* }} \\
(0.0009)\end{array}$ \\
\hline FORCORP*SIZE & $\begin{array}{l}0.00003 \\
(0.0008)\end{array}$ & $\begin{array}{l}-0.0009 \\
(0.0007)\end{array}$ \\
\hline DOMFIN*SIZE & $\begin{array}{l}-0.00039 \\
(0.0008)\end{array}$ & $\begin{array}{l}-0.0004 \\
(0.0008)\end{array}$ \\
\hline DOMCORP*SIZE & $\begin{array}{l}-0.00045 \\
(0.0004)\end{array}$ & $\begin{array}{l}-0.0004 \\
(0.0005)\end{array}$ \\
\hline FORFIN*TURNOVER & $\begin{array}{c}0.0266 \\
(0.0327)\end{array}$ & $\begin{array}{c}0.0278 \\
(0.0328)\end{array}$ \\
\hline FORCORP*TURNOVER & $\begin{array}{l}0.1794 * * \\
(0.0832)\end{array}$ & $\begin{array}{l}0.1997 * * \\
(0.0891)\end{array}$ \\
\hline DOMFIN*TURNOVER & $\begin{array}{l}-0.0603 \\
(0.0435)\end{array}$ & $\begin{array}{l}-0.0584 \\
(0.0440)\end{array}$ \\
\hline DOMCORP*TURNOVER & $\begin{array}{l}-0.0240 \\
(0.0207)\end{array}$ & $\begin{array}{l}-0.02335 \\
(0.0207)\end{array}$ \\
\hline FORFIN^2 & & $\begin{array}{l}-0.0007 \\
(0.0056)\end{array}$ \\
\hline FCORP^2 & & $\begin{array}{l}0.0319 * 1 * \\
(0.0117)\end{array}$ \\
\hline DOMFIN^2 & & $\begin{array}{c}0.0088 \\
(0.0054)\end{array}$ \\
\hline DOMCORP^2 & & $\begin{array}{c}0.0070 \\
(0.0055)\end{array}$ \\
\hline $\begin{array}{l}\text { Sargan test } \\
\text { (p-value) } \\
\text { Hansen test } \\
\text { (p-value) } \\
\text { AB test for AR(2) } \\
\text { (p-value) } \\
\text { No. of Instruments }\end{array}$ & $\begin{array}{c}15.00 \\
(0.722) \\
18.85 \\
(0.467) \\
1.30 \\
(0.193) \\
53\end{array}$ & $\begin{array}{c}15.05 \\
(0.719) \\
18.07 \\
(0.518) \\
1.28 \\
(0.200) \\
57\end{array}$ \\
\hline No. of Observations & 8014 & 8014 \\
\hline
\end{tabular}

*significant at 10 percent level; **significant at 5 percent level; ***significant at 1 percent level.

$A B$ test for $A R(2)$ : test of residuals second order autocorrelation (Arellano \& Bond, 1991). 


\section{Jurnal Keuangan dan Perbankan | KEUANGAN}

Vol. 19, N 0.3, September 2015: 357-367

tic] institutional ownership (FORIN ST ) [D O M IN ST ] is decomposed into (foreign) [domestic] financial institutional ownership (FORFIN) [DORFIN] and (foreign) [domestic] non-financial corporation (FOR CORP) [D OM CORP] ownership. The complete results of the additional test are presented in Table 4.

A fter the decomposition of FORIN ST, models (3) and (4) show that the coefficients of FORFIN are significantly positive, while the coefficients of FORCORP are insignificant. This shows that foreign financial institutional ownership significantly impact stock return volatility, while foreign nonfinancial corporation ownership does not seem to affect return volatility.H owever, the destabilizing impact of FO RFIN is weaker for larger cap stocks. This can be confirmed from the coefficients ofFO RFIN *SIZE which are significantly negativein both models. In contrast, all interaction terms with SIZE are not significantin both models.

Interestingly, the non-linear impact on volatility is generated by foreign non-financial institutional ownership. This inferenceis drawn from the coefficient of FCORP^ 2 in model (4) which is positively significant. Consistent with the base model results, domestic institutional ownerships represented by DOM FIN and DOM CORP do not linearly or non-linearly impact return volatility.

It is also interesting to learn that the coefficients of FCORP*TU RN OVER aresignificant in both models. It can be inferred that foreign non-financial ownership in highly traded stocks tends to increase stock return volatility. In other words, the foreign corporation ownership in high turnover stocks may destabilize the Indonesian market.

\section{Concluding Remarks}

This research aims to study the impact of foreign institutional ownership on contemporaneous stock return volatility in Indonesian market. In this study, foreign and domestic institutional ownership consists of: (1) insurance, (2) pension fund, (3) investment bank, (4) mutual fund, (5) stock brokerage company, and (6) corporation; while return volatility is measured as standard deviation of daily stock returns.

Results from dynamic panel data models support all three main hypotheses. Firstly, foreign institutional ownership (FORINST) linearly increases contemporaneous monthly stock return volatility. Secondly, foreign institutional ownership linear impact is weaker for stocks with large market capitalization. Thirdly, foreign institutional ownership convexly increases monthly stock return volatility.

Further test results show that foreign financial institutional ownership (FORFIN) linearly escalatesstock return volatility, while foreign nonfinancial corporationownership (FORCORP) convexly increases stock return volatility. The additional test also indicates thatboth domestic financial and non-financial institutional ownershipsdo not impact stock return volatility. Hence, domestic institutional investors may play a significant stabilizing role in the Indonesian market.

Indonesian market policy makers and stake holders should realize that although Indonesia needs foreign institutional capital to flow into its economy, the foreign capital flow may destabilize the market. Henceforth, they also need to continuously strengthen domestic institutional investors for they are the potential stabilizers of the Indonesian market.Moreover, increasing market capitalization of stocks may reduce the destabilizing impact of foreign institutional ownerships.

One of the limitations of this study is that it omits foreign and domestic individual ownerships. The omission is based on the assumption that individual ownershipsin Indonesia areinsignificant compared to institutional ownerships. Further studies should consider individual investors roles in the Indonesian market. 


\section{Foreign Institutional Ownership Andstock Return Volatility In Indonesia}

Irwan Adi Ekaputra

\section{REFERENCES}

Arellano, M., \& Bond, S. (1991). Some tests of specification for panel data: Monte Carlo evidence and an application to employment equations. R eview of Economics Studies, 58(2), 277-297.

Arellano, M., \& Bover, O. (1995). A nother look at the instrumental variableestimation of error-components models. Journal of Econometrics, 68(1), 29-51.

Bae, K.-H., Chan, K., \& Ng, A. (2004). Investibility and return volatility. Journal of Financial Economics, 71(2), 239-263.

Bae, K.-H., Ozoguz, A., Tan, H., \& Wirjanto, T. S. (2012). Do foreigners facilitate information transmission in emerging markets? Journal of Financial Economics, 105(1), 209-227.

Bekaert, G., \& Harvey, C. R. (1997). Emerging equity market volatility. Journal of Financial E conomics, 43(1), 29-77.

Bekaert, G., \& Harvey, C. R. (2000). Foreign speculators and emerging equity markets. Journal of Finance, 55(2), 565-613.

Bekaert, G., Harvey, C. R., \& Lundblad, C. (2005). Does financial liberalization spur growth? Journal of $\mathrm{Fi}-$ nancial Economics, 77(1), 3-55.

Bekaert, G., Harvey, C. R., \& Lundblad, C. (2011). Financial opennes and productivity. W orld D evelopment, 39(1), 1-19.

Blundell, R., \& Bond, S. (1998). Initial conditions and moment restrictions in dynamic panel data models. Journal of Econometrics, 87(1), 115-143.

Bonser-Neal, C., Linnan, D., \& Neal, R. (1999). Emerging market transaction costs: Evidence from Indonesia. Pacific-Basin Finance Journal, 7(2), 103-127.

Chen, Z., Du, J., Li, D., \& Ouyang, R. (2013). Does foreign institutional ownership increase return volatility? Evidence from China. Journal of Banking \& Finance, 37(2), 660-669.

Dahlquist, M., \& Robertsson, G. (2001). Direct foreign ownership, institutional investors, and firm characteristics. Journal of Financial Economics, 59(3), 413440.

de la Torre, A., Gozzi, J. C., \& Schmukler, S. L. (2007). Stock market development under globalization: Whither the gains from reforms? Journal of Banking \& Finance, 31(6), 1731-1754.
Esqueda, O. A., Assefa, T. A., \& Mollick, A. V. (2012). Financial globalization and stock market risk. Journal of International Financial M arkets, Institutions \& M oney, 22(1), 87-102.

Gourinchas, P.-O., \& Jeanne, O. (2006). The elusive gains from international financial integration. Review of Economic Studies, 73(3), 715-741.

Henry, P. B. (2000). Stock market liberalization, economic reform, and emerging market equity prices. Journal of Finance, 55(2), 529-564.

Huang, W., \& Zhu, T. (2014). Foreign institutional investors and corporate governance in emerging markets: Evidence of a split-share structure reform in China. Journal of Corporate Finance, Article in Press.

Li, D., Nguyen, Q. N., Pham, P. K., \& Wei, S. X. (2011). Large foreign ownership and firm-level stock re turn volatility in emerging markets. Journal of $\mathrm{Fi}$ nancial and Q uantitative A nalysis, 46(4), 1127-1155.

Nickell, S. (1981). Biases in dynamic models with fixed effects. Econometrica, 49(6), 1471-1426.

Rhee, S. G., \& Wang, J. (2009). Foreign institutional ownership and stock market liquidity: Evidence from Indonesia. Journal of Banking \& Finance, 33(7), 13121324.

Schuppli, M., \& Bohl, M. T. (2010). Do foreign institutional investors destabilize China's A-share markets? Journal of International Financial M arkets, Institutions \& M oney, 20(5), 36-50.

Stiglitz, J. E. (2002). Capital market liberalization and exchange rate regimes: Risk without reward. A nnals of the A merican A cademy of Political and Social Science, 579, 219-248.

Stoffman, N. (2014). Who trades with whom? Individuals, institutions, and returns. Journal of Financial $M$ akets, 21, 50-75.

Umutlu, M., Akdeniz, L., \& Altay-Salih, A. (2010). The degree of financial liberalization and aggregated stock-return volatility in emerging markets. Journal of Banking \& Finance, 34(3), 509-521.

Wang, J. (2007). Foreign equity trading and emerging market volatility: Evidence from Indonesia and Thailand. Journal of D evelopment Economics, 84(2), 798-811.

Wang, J. (2013). Theimpact of foreign ownership on stock volatility in Indonesia. A sia-Pacific Journal of Financial Studies, 42(3), 493-509. 